\title{
Analysis of Challenges Related to Poor Environmental Regulatory Framework on Mineral Exploration Projects: A Case of Tanzania
}

\author{
Meserecordias Wilfred Lema \\ Department of Environmental Engineering and Management, School of Environmental Sciences and \\ Technology, College of Earth Sciences, University of Dodoma, Dodoma, Tanzania \\ Email: drlemaofficial@gmail.com
}

Received 3 June 2016; accepted 22 July 2016; published 25 July 2016

Copyright (C) 2016 by author and Scientific Research Publishing Inc. This work is licensed under the Creative Commons Attribution International License (CC BY). http://creativecommons.org/licenses/by/4.0/

(c) (i) Open Access

\section{Abstract}

In the United Republic of Tanzania (URT), all environmental issues related to the mining industry are regulated according to two principle Acts: The Mining Act and the Environmental Management Act, and their respective regulations. The current acts were enacted in 2010 and 2004 respectively. Mineral exploration (that includes all on-site activities performed before a mining project is declared feasible) projects in URT appears to be "unforgotten phenomena" in the two major legislative documents, when it comes to environmental considerations. This phenomenon is believed to be causing detrimental effects to the environment. This paper, therefore, analyzes the current environmental regulatory framework on mineral exploration projects in URT and discusses few examples in which mineral exploration projects have caused damage to the indigenous environment. Furthermore, this study reviews environmental regulatory frameworks from other few countries in comparison with existing environmental regulatory framework prevailing in URT.

\section{Keywords}

Mineral Exploration Projects, Mining, Environment Regulatory Framework

\section{Introduction}

Mining means extraction of valuable minerals. It is the extraction of valuable minerals or geological materials from the earth crust which forms the mineralized package of economic interest to the miner [1] [2]. There are 
four main stages associated with any mining project, which are: mineral exploration, actual mining, mineral beneficiation and project decommissioning (rehabilitation) [3]. The first stage involves all activities related to searching for valuable minerals that can be mined at a profit. These include area selection, target generation, resource evaluation and reserve definition, all of which aim at defining a mineral reserve with a high confidence level in order to allow a profitable mining project to be undertaken [3]. All the other three stages depend on the first stage (mineral exploration) for their existence.

Exploration means search for resources. Exploration is the act of searching or travelling a terrain for the purpose of discovery of resources [4]. Mineral exploration involves the search for mineral accumulations which can be profitably mined [3]. According to [5], mineral exploration is the process undertaken by companies, partnerships or corporations in the endeavor of finding ore (commercially viable concentrations of minerals) to mine. It may be defined as the activities of evaluating a geologic prospect to determine its size, shape, grade, and profit potential [2]. Mineral exploration is a much more intensive, organized and professional form of mineral prospecting and, though it frequently uses the services of prospecting, the process of mineral exploration on the whole is much more involving. Every new mine must undergo mineral exploration before its economic viability can be established.

Unfortunately, the extent of the significance of the impacts of mineral exploration activities to the environment is not very clear to a number of stakeholders [3]. This is possibly due to the fact that exploration activities are either not very much understood or being ignored [3] [6] [7]. In the context of environmental management, mineral exploration can be divided into three main phases; the first phase is area selection that involves activities such as geological literature studies, map compilation, geological field studies and land acquisition. This initial phase is believed to have almost zero impacts due to the fact that all activities involved are either office work or half office and half field visit. The second phase is target generation which involves sampling through geophysical methods, geochemical methods and remote sensing. This phase is believed to have minimal and short term impacts that can all be reversible since it involves low-flying aircraft and few earth disturbing activities such as trenching and pitting. These activities are field based and are always associated with hydrocarbon spillage (minimal use of light vehicles and other smaller machines), few leftovers such as sample bags, food remains, and fuel drum [3]. The third phase involves detailed studies for assessment of mineral deposits through resource evaluation and reserve definition. This stage has very significant environmental and social-economic impacts (depending on the life span and the size of that particular exploration project). Activities such as drilling of boreholes (both core samples and rock chips drilling), trenching, site clearance, camp construction and the increase in the number of workers at site may cause substantive environmental impacts including air, water, noise and land pollution, disturbance to flora and fauna, camp garbage, hydrocarbon spillage, generation of metallic and plastic scrappers at site, land alienation, erosion as well as acid mine drainage [3].

As it has been defined earlier, mineral exploration simply means "the search for mineral resources" while mining means "the extraction of resources". Mineral exploration is usually performed before mining and in that way mineral exploration stands as an independent project that may or may not result into a mining project [8]. The only major difference between the two is that a mineral exploration project has a shorter lifespan (usually 4 years) compared to a mining project that may take up to 25 years. Also, the former is normally regarded as a temporary endeavor while the latter is considered permanent. Unlike mining projects which have several tools for their environmental assessment, exploration projects in Tanzania lack such tools. In the mining projects, there are special tools such as Environmental Impact Assessment, Environmental Audit, Environmental Accounting, Environmental Management and Monitoring and many other [9] [10]. The situation is different when it comes to exploration projects. There are neither special tools nor mandatory requirements that may offer a methodological guide for environmental assessment in the exploration projects.

This research work intends to analyze the current environmental regulatory framework on mineral exploration projects in the United Republic of Tanzania (URT). In line with that, this study shall use data from other studies conducted on one Uranium exploration project (in URT) to discuss environmental challenges that may arise during minerals exploration. Finally, this study reviews environmental regulatory frameworks from other few countries in comparison with existing environmental regulatory framework prevailing in URT.

\section{Environmental Regulatory Framework in URT}

The principal Act that regulates all mining (including mineral exploration) projects in URT is called the Mining 
Act, 2010 [11]. This principal legislation was then equipped with regulations, providing for its clear guidance for administration and enforcement. The regulations that are associated with the Mining Act, 2010 are known as “The Mining (Environmental Management and Protection) Regulations, 2010” [12]. Likewise, all environmental aspects in all projects, before and after their commencement are regulated according to the Environmental Management Act, 2004 [9] and the Environmental Impact Assessment and Audit Regulations, 2005 [10]. This act triggered the establishment of the National Environment Management Council (NEMC) that was then given power to undertake enforcement, compliance, review and monitoring of environmental impact assessment and in that regard, to facilitate public participation in environmental decision making, exercise general supervision and coordination over all matters relating to the environment. In 2005, the Environmental Impact Assessment and Audit Regulations were made. The document provides all the necessary requirements, steps, procedures and guidelines to be followed by an individual or organization wanting to undertake a project that might cause adverse impacts to the surrounding environment once undertaken, be it small, medium or large scale. The document also outlines a list of all projects that require undertaking of both Environmental and Social Impact Assessment (ESIA) and Environmental Management Plan (EMP) [13]. Unfortunately, mineral exploration projects are not discussed thoroughly in any of the two principal documents mentioned above.

\subsection{The Mining Act of URT}

As it has been discussed in the previous sections of this paper, the Mining Act, 2010 regulates the mining industry in URT. A thorough review of the Mining Act, 2010 has revealed that the whole document does not discuss anything regarding environmental obligations for holders of prospecting (mineral exploration) licenses. Going through the specific section that talks about prospecting licenses in the Mining Act, 2010 (Part IV, Division A, Section 34-1), it was discovered that the section only covers a number of common aspects including; application procedures, license area to be covered, grant duration, description and plan of the area of land over which the license is granted, description of the prospecting/exploration programme and its financial expenditure estimate, and description of the procurement plan of goods and services within the United Republic. Unfortunately, the whole document does not give any provisions regarding environmental aspects on mineral exploration projects.

\subsection{The Mining (Environmental Management and Protection) Regulations of URT}

The Mining (Environmental Management and Protection) Regulations of 2010 is crafted to provide for sustainable environment management in a mining site. The Mining (Environmental Management and Protection) Regulations, in a short form MEMPR stipulates the significance of including Environmental Impact Assessment and Environmental Management Plan in all mineral rights applications for special mining licenses, mining licenses and gemstone mining licenses. Also MEMPR provides for specific mine closure procedures upon completion of a mining project to ensure that the closure of mines is done with the least possible negative impact on local communities and the indigenous environment. Surprisingly, nothing has been mentioned on the environmental obligations for the holder of a prospecting (mineral exploration) license.

It is therefore very evident that the Mining Act of URT, 2010 and its associated regulations do not provide for environmental obligation for all individuals or companies undertaking mineral explorations in the states territory. Consequently, it's therefore high time for all national environmental regulatory bodies to start devising mechanisms for establishment of environmental legislations that will guide all holders of prospecting licenses towards proper consideration of environmental matters related to their projects.

\subsection{The Environmental Management Act (2004) of URT}

Unlike Mining Act (2010), the Environmental Management Act number 28 of 2004 has several sections that cover the general environmental obligations. Firstly, part II, section 6 states the general obligation of every person living in Tanzania; to protect, safeguard and enhance the environment and inform the authority of any activity that may affect the environment significantly. Secondly, section 6 of the third schedule of the same Act lists the types of projects that require Environmental Impact Assessment (EIA) to be undertaken as a mandatory requirement. In this category only Mining, Quarrying and Open-cast extraction projects are mentioned. Therefore, it is very clear that mineral exploration projects are not considered to be environmentally dangerous, which is a very wrong conception/generalization. 


\subsection{The Environmental Impact Assessment and Audit Regulations of URT}

The Environmental Impact Assessment and Audit Regulations, 2005 provide for specific procedures and guidelines that need to be followed when submitting an EIA prior to commencing work on any new project. To determine whether a full EIA is required, the first schedule to these regulations contains the classification for Type A and Type B projects. Type A projects will be deemed to have a significant adverse impact on the environment and will require a full EIA prior to their commencement. Type B projects are those that are deemed unlikely to have a significant impact on the environment and, as a result, will only require a preliminary EIA. During screening process, following the submission of a project brief to the National Environmental Management Council (NEMC), a project is classified accordingly. Details of the various types of projects that belong to each category are as follows.

\subsubsection{Type A-Project Requiring a Mandatory EIA}

Projects which are likely to have significant adverse environmental impacts and that in-depth study is required to determine the scale, extent and significance of the impacts and to identify appropriate mitigation measures are listed in this category. Section 16 of these regulations (Extractive Industries) has mentioned the following types of projects; Extraction of petroleum, Extraction and purification of natural gas, other deep drilling-bore-holes and wells and Mining. There is no mineral exploration projects in this category.

\subsubsection{Type B-Project Requiring Preliminary Environmental Assessment}

This category contains projects which are likely to have some adverse environmental impacts but that the magnitude of the impacts is not well-known. In this category, a preliminary environmental assessment is required to decide whether the project can proceed without a full environmental impact assessment. This category mentions only artisanal and small scale mining. This group has the same weakness as well. There is nothing specific on mineral exploration projects.

\section{Mineral Exploration Activities and Their Typical Potential Adverse Impacts}

Research [6] [14]-[16] has shown that mineral exploration projects may bring adverse impacts to the indigenous communities and the natural environment. This is the main reason for European countries i.e. Australia; and other African countries i.e. South Africa, Zambia and Zimbabwe have decided to consider mineral exploration projects as the type of projects that are likely to cause significant adverse environmental impacts to the communities, in and around the prospecting licenses[17]-[20]. Table 1 describes typical significant adverse impacts that are likely to be caused by each of the three main stages of a mineral exploration project.

Table 1. Mineral exploration activities and their expected environmental impacts.

\begin{tabular}{ccl}
\hline $\begin{array}{c}\text { Main stages of } \\
\text { uranium exploration }\end{array}$ & Main activities & Expected environmental impact \\
\hline $\begin{array}{c}\text { Stage 01 } \\
\text { Area selection }\end{array}$ & $\begin{array}{c}\text { Geogical literature studies and } \\
\text { maps compilation } \\
\text { Geological field studies } \\
\text { Land acquisition }\end{array}$ & No significant impact \\
\hline $\begin{array}{c}\text { Trenching } \\
\text { Parget generation } 02\end{array}$ & $\begin{array}{c}\text { Geophysical methods } \\
\text { Geochemical methods } \\
\text { Remote sensing }\end{array}$ & $\begin{array}{c}\text { Minimal significant impact i.e. minimal air, water, noise and land } \\
\text { pollution; minimal disturbance to flora and fauna; minimal garbage, } \\
\text { hydrocarbon spillage; and little scrappers at site }\end{array}$ \\
\hline $\begin{array}{c}\text { Stage 03 } \\
\text { Resource evaluation } \\
\text { and reserve definition }\end{array}$ & $\begin{array}{c}\text { Drilling (Phase I) } \\
\text { Drilling (Phase II) } \\
\text { Drilling (Phase III) } \\
\text { Other auxiliary activities i.e. site } \\
\text { clearing and camp construction }\end{array}$ & $\begin{array}{l}\text { Significant adverse impact i.e. air, water, noise and land pollution; } \\
\text { significant disturbance to flora and fauna; camp garbage, hydrocarbon } \\
\text { spillage; and metallic and plastic scrappers at site }\end{array}$ \\
\hline
\end{tabular}

Source: [3]. 
In the last decade, significant Uranium ore reserves have been discovered in URT, welcoming potential investment opportunities for the establishment of new mining projects in the country [15] [16]. Taken as a case study, the Mkuju River Uranium (MRU) exploration project is one of potential mineral exploration projects that are expected to result into a mega mining project in the future [3]. Two independent studies were undertaken in 2009 and 2010 to assess the significance of adverse environmental impacts that were likely to be caused by MRU exploration project. Results of these two studies were reported in two different Masters' Degree Dissertations in 2010 [3] and 2011 [7] consecutively. A review of the two studies has revealed the following important facts.

\subsection{A Review from the First Study [3]}

This study was aimed at assessing the level of environmental pollution caused by the activities undertaken by MRU exploration project. Therefore, from this study, the following main parameters were used to estimate the level of pollution caused by MRP exploration project; physical inspection, air quality and water quality. The following were the results;

\subsubsection{Results from Physical Inspection}

In Table 2, physical impacts observed at MRU exploration site are summarized.

\subsubsection{Air Quality Results}

1) Dust and noise

In Table 3, a summary of dust and noise level measured in and around MRU exploration site is provided. From this table, it is observably clear that all the five specific areas at campsite had noise levels beyond the allowed limit of $75 \mathrm{~dB}$ [21]. Furthermore, one area (RC drilling) had dust levels above the allowable limit of 5 $\mathrm{mg} / \mathrm{m}^{3}[21]$.

Table 2. Summary of the identified physical effects.

\begin{tabular}{|c|c|c|c|}
\hline $\mathrm{S} / \mathrm{N}$ & Identified effect & Possible cause & Impacts \\
\hline 1. & $\begin{array}{l}\text { Dust deposition on vegetation and } \\
\text { tents }\end{array}$ & $\begin{array}{l}\text { Fine and ultra-fine particles from drilling } \\
\text { activities and vehicles travelling on dusty } \\
\text { roads }\end{array}$ & $\begin{array}{l}\text { Dust especially from radioactive minerals is } \\
\text { very dangerous if inhaled }\end{array}$ \\
\hline 3 & $\begin{array}{l}\text { Scrap metal left unattended for } \\
\text { long periods of time }\end{array}$ & $\begin{array}{l}\text { No specific policy on disposal of scrap } \\
\text { metal }\end{array}$ & $\begin{array}{l}\text { Rust increases the amount of iron in water } \\
\text { streams and underground water }\end{array}$ \\
\hline 4 & $\begin{array}{l}\text { Waste piles of oil-contaminated } \\
\text { soil in plastic bags }\end{array}$ & Lack of a bioremediation plant & Oil spills add hydrocarbons to soil \\
\hline 5 & $\begin{array}{l}\text { Effluent water discharge into } \\
\text { underground water sources and } \\
\text { water wells. }\end{array}$ & $\begin{array}{l}\text { By-pass and negligence of environmental } \\
\text { procedures during Uranium exploration } \\
\text { activities at site }\end{array}$ & $\begin{array}{l}\text { Water pollution especially from metallic } \\
\text { minerals and its associates is very harmful to } \\
\text { human, plant and animal lives }\end{array}$ \\
\hline 6 & $\begin{array}{l}\text { Land, flora and fauna } \\
\text { disturbance. }\end{array}$ & $\begin{array}{l}\text { Improper supervision by the concerned } \\
\text { authorities }\end{array}$ & $\begin{array}{l}\text { Soil erosion, death and disturbance of } \\
\text { vegetation and animals occur }\end{array}$ \\
\hline 8 & Noise & $\begin{array}{l}\text { Heavy equipment in operation and } \\
\text { generators while working }\end{array}$ & $\begin{array}{l}\text { Disturbs human and animals' mental } \\
\text { equilibrium }\end{array}$ \\
\hline 9 & $\begin{array}{l}\text { Acidic water from the uncovered } \\
\text { pits and trenches }\end{array}$ & $\begin{array}{l}\text { Effect of acid rock drainage if acidic rock } \\
\text { is present in the project area }\end{array}$ & $\begin{array}{l}\text { Acidic water changes the } \mathrm{pH} \text { of water which } \\
\text { makes it difficult for normal use unless } \\
\text { neutralized }\end{array}$ \\
\hline
\end{tabular}

Source: [3].

Table 3. Average noise and dust measurements that were above allowable limits.

\begin{tabular}{ccc}
\hline Area & Dust $\left(\mathrm{mg} / \mathrm{m}^{3}\right)$ & Noise $(\mathrm{dB})$ \\
\hline Around generator set & BSL $^{*}$ & 80.7 \\
At camp & BSL & 76.4 \\
Around water pump & BSL & 102.9 \\
RC drilling & 6.48 & 113 \\
Diamond drilling & BSL & 99.8 \\
\hline
\end{tabular}

*Below standard limit dust (5 mg/m³); noise (75 dB); source: [21]. 


\subsubsection{Water Quality Results}

Water samples from five rivers (as shown in Table 4), that were analyzed for several parameters including electrical conductivity (EC), total dissolved solids (TDS), and trace elements (Iron, Manganese, Cadmium and Chromium) were found polluted. One river (River Kilowero) had all trace metals above the accepted limits, another river (River Umbalilo) contained high levels of total dissolved solids beyond allowable limits and the third river (River Mkuju) had both electrical conductivity and total dissolved solids beyond acceptable standards. The study concluded that, it is mineral exploration activities that had caused pollution to all the three rivers available in the project site.

\subsection{A Review from the Second Study [7]}

This study was undertaken to provide details on radioactivity levels and heavy metals concentration prior to establishment of a mining project, had the MRU exploration project proved feasible. Samples were taken from soil, sediments and water. Results from this study were to provide a pre-mining background data for future environmental pollution monitoring.

\section{Results for Radioactivity Levels and Heavy Metals Concentration}

The activity concentrations in soil and sediments from Mkuju uranium deposit were higher than the world average of 35, 30 and $500 \mathrm{Bqkg}-1$ for ${ }^{238} \mathrm{U},{ }^{232} \mathrm{Th}$ and ${ }^{40} \mathrm{~K}$, respectively [23]. The activity concentrations in water samples were comparable to control samples and other uranium mineralization areas reported in the literatures [24]. The concentration of heavy metals in soil, sediments and water samples on $\mathrm{Cr}, \mathrm{Fe}, \mathrm{Zn}, \mathrm{Pb}$, Th and U were found to be higher than the control samples but not above the allowed limits [25].

\subsection{Empirical Review from Other Countries' Regulatory Framework towards Mineral Exploration Projects}

The current practice in the Republic of South African (RSA) requires all companies seeking for prospecting licenses in RSA to submit environmental management plans, which involve consultation with the owners or lawful occupiers of the land in question [18]. Other African countries such as Zambia and Zimbabwe have a general rule concerning all establishment of development of any project (regardless of its size) to prepare a report or a project brief that must address key issues such as the description of the site, proposed activities, and all aspects of potential environmental impact. This report will determine the viability of the project whether to be undertaken with or without a full EIA study [19] [20].

The Australian Mining Act of 1971 describes clearly the environmental protection guides to an application of a mineral exploration license. It states that "Any holder of an exploration license must observe protection of the natural beauty of any locality or place that may be affected by the conduct of operations in pursuance of the license, protection of flora and fauna that may be endangered or disturbed by those operations, protection of buildings of architectural or historical interest, and objects and features of scientific or historical interest, that may be affected by those operations and protection of any Aboriginal sites or objects within the meaning of the Aboriginal Heritage Act 1988 that may be affected by those operations, and may take into consideration such other factors as he considers appropriate in the particular case [17].

\section{Conclusion and Recommendations}

This study has revealed a significant loophole in the current regulatory framework in URT in relation to

Table 4. Summary of water quality analysis results versus Tanzanian/WHO standards.

\begin{tabular}{cccccccc}
\hline $\begin{array}{c}\text { Parameter } \\
\text { Location } \boldsymbol{\nabla}\end{array}$ & $\begin{array}{c}\mathrm{Cd} \\
(\mathrm{mg} / \mathrm{l})\end{array}$ & $\begin{array}{c}\mathrm{Cr} \\
(\mathrm{mg} / \mathrm{l})\end{array}$ & $\begin{array}{c}\mathrm{Mn} \\
(\mathrm{mg} / \mathrm{l})\end{array}$ & $\begin{array}{c}\mathrm{Fe} \\
(\mathrm{mg} / \mathrm{l})\end{array}$ & $\begin{array}{c}\mathrm{EC} \\
(\mu \mathrm{s} / \mathrm{cm})\end{array}$ & $\begin{array}{c}\mathrm{TDS} \\
(\mathrm{mg} / \mathrm{l})\end{array}$ \\
\hline Kilowelo R & 0.06 & 0.07 & 0.8 & 2.53 & 104.2 & 45.4 \\
Mkuju R & 0.0 & 0.0 & 0.0 & 0.09 & 452.0 & 248.6 \\
Umbalilo R & 0.0 & 0.0 & 0.0 & 0.03 & 394.0 & 216.7 \\
Tanzanian/WHO Std $^{*}$ & $\mathbf{0 . 0 5}$ & $\mathbf{0 . 0 5}$ & $\mathbf{0 . 5}$ & $\mathbf{1}$ & $\mathbf{4 0 0}$ & $\mathbf{2 0 0}$ \\
\hline
\end{tabular}

*Source: [11] [12] [22]; Red highlight means “above the limits”. 
environmental issues in the mineral exploration sector. Activities related to such projects may cause a significant detrimental impact to the natural environment if proper and timely measures are not taken. The fact that, the two principal legislative documents (Environmental Management Act, 2004 and Mining Act, 2010) that regulate both Mining and Environmental matters in the country are completely silent on this matter, adds more fuel towards the danger of destructions to our natural environment. Furthermore, studies by Wilfred (2010) and Mwalongo (2011) described in this report have vividly shown that mineral exploration activities may cause a significant level of negative environmental impacts. Not only that, but also other countries including Australia and other African countries earlier mentioned in this report provide further emphasis on the need for URT to improve its mining and environmental legislative framework to accommodate issues related to environmental protection in mineral exploration projects. To start with, mineral exploration projects should be listed in Type B projects stipulated in the Environmental Impact Assessment and Audit Regulations, 2005. This is a list of projects that require preliminary environmental assessment before they are undertaken. This category contains projects which are likely to have some adverse environmental impacts but that the magnitude of the impacts is not well-known. In this category, a preliminary environmental assessment is required to decide whether the project can proceed without a full environmental impact assessment or not.

\section{References}

[1] Hartman, H.L. (1992) SME Mining Engineering Handbook. Society for Mining, Metallurgy, and Exploration Inc., 3.

[2] Hartman, H.L. and Mutmansky, J.M. (2002) Introductory Mining Engineering. John Wiley \& Sons.

[3] Wilfred, M. (2010) Environmental Assessment of Uranium Exploration Projects: A Case Study of Mkuju River Uranium Exploration Project. Unpublished Masters’ Thesis, University of Dar es Salaam, Tanzania.

[4] BP Hall (2009) What Does Exploration Mean? www.dictionary.net

[5] Dyni, J.R. (2006) Geology and Resources of Some World Oil-Shale Deposits. Scientific Investigations Report 20055294, U.S. Department of the Interior, U.S. Geological Survey.

[6] Dorin, F. (2009) Environmental Impact of Uranium Mining. Article for National Uranium Company SA Bucharest, Romania, Published at 68 Dionisie Lupu Street.

[7] Mwalongo, D. (2011) Determination of Background Radioactivity Levels and Elemental Composition at Mkuju Uranium Deposit in Tanzania. Unpublished Masters' Thesis, University of Dar es Salaam, Tanzania.

[8] Kennedy, B.A. (1990) Surface Mining. 2nd Edition, Port City Press, Maryland.

[9] URT (United Republic of Tanzania) (2004) National Environmental Management Act. www.tanzania.go.tz

[10] United Republic of Tanzania (2005) The Environmental Impact Assessment and Audit Regulations. www.tanzania.go.tz

[11] United Republic of Tanzania (2010) Mining Act. www.mem.go.tz

[12] United Republic of Tanzania (2010) Mining (Mineral Rights) Regulations. www.mem.go.tz

[13] Mutagwaba, W. (2006) Analysis of the Benefits and Challenges of Implementing Environmental Regulatory Programmes for Mining: Tanzania Case Study. Journal of Cleaner Production, 14, 397-404. http://dx.doi.org/10.1016/j.jclepro.2004.02.045

[14] Krockenberger, M. (1997) Environmental Effects of Uranium Mining in Australia. Journal of Unclean, Unsafe \& Unwanted-The Nuclear Industry Nightmare, Published by, Australian Conservation Foundation.

[15] Edwin, W. (2009) Uranium Discovered in Tanzania Mining Sector. www.tanzaniainvest.com

[16] Obulutsa, G. (2009) Tanzania Has Significant Uranium Deposits. www.mineweb.com

[17] SAL (South Australia Legislation) (1971) Mining Act. www.legislation.sa.gov.au

[18] RSA (Republic of South Africa) (2016) Digging for Mining Licenses. www.iaia.co.za

[19] RZa (Republic of Zambia) (2016) Mining in Zambia-Overview. www.mbendi.com

[20] RZim (Republic of Zimbabwe) (2016) Mining in Zimbabwe-Overview. www.mbendi.com

[21] OSHA US (United States Occupational Safety \& Health Administration) (2010) Permissible Exposure Limits. http://www.osha.gov/SLTC/pel/

[22] WHO World Health Organization (2006) Guidelines for Drinking-Water Quality, 3rd Edition.

[23] UNSCEAR (United Nations Scientific Committee on the Effects of Atomic Radiation) (2000) Sources and Effects of Ionizing Radiation, UNSCEAR 2000 Report to the General Assembly, With Scientific Annexes, Vol. 1: Sources. 
[24] Kurnaz, A., Kucukomeroglu, B., Keser R., Okumusoglub, N.T., Korkmazb, F., Karahan, G. and Cevik, U. (2007) Determination of Radioactivity Levels and Hazards of Soil and Sediment Samples in Firtına Valley (Rize, Turkey). Applied Radiation and Isotopes, 65, 1281-1289. http://dx.doi.org/10.1016/j.apradiso.2007.06.001

[25] US-EPA (United States Environmental Protection Agency) (2006) XRF Technologies 71 for Measuring Trace Elements in Soil and Sediment. Innovative Technology Verification Report, Contract No. 68-C-00-181 Task Order No. 42.

Submit or recommend next manuscript to SCIRP and we will provide best service for you:

Accepting pre-submission inquiries through Email, Facebook, Linkedin, Twitter, etc A wide selection of journals (inclusive of 9 subjects, more than 200 journals)

Providing a 24-hour high-quality service

User-friendly online submission system

Fair and swift peer-review system

Efficient typesetting and proofreading procedure

Display of the result of downloads and visits, as well as the number of cited articles Maximum dissemination of your research work

Submit your manuscript at: http://papersubmission.scirp.org/ 